\title{
Desafio da Construcão Civil: crescimento com sustentabilidade ambiental
}

\author{
Angela Borges Masuero ${ }^{1}$
}

\author{
${ }^{1}$ Editora Assistente
}

Universidade Federal do Rio Grande do Sul - UFRGS, Núcleo Orientado para Inovação da Edificação NORIE, Av. Osvaldo Aranha, 99, 90035-190, Porto Alegre, RS, Brasil.

E-mail: angela.masuero@ufrgs.br

A indústria da construção civil sempre teve um papel de grande importância social e econômica, em especial em períodos de crise como o da pandemia Covid-2019. Ela movimenta uma grande cadeia produtiva, alavanca o crescimento econômico e a geração de empregos de uma forma rápida, e é responsável por uma parcela significativa do PIB, por um grande número de postos de trabalho e uma parcela considerável da geração de renda para a população. Por outro lado, a indústria da construção civil tem um impacto ambiental negativo, com um alto consumo de insumos naturais esgotáveis, alta demanda energética, alta geração de resíduos e de emissão de $\mathrm{CO}_{2}$. Segundo a ONU [1], a estimativa é que até 2050, a população mundial que vive em áreas urbanas passe dos atuais 55\% para aproximadamente $70 \%$. O grande desafio será atender a demanda de infraestrutura e moradia decorrente dessa maior concentração urbana com o menor impacto ambiental possível. Até hoje, o crescimento do bem-estar humano e o desenvolvimento econômico têm sido associados ao rápido aumento do uso de recursos naturais, como energia, materiais e água [2]. Contudo, frente ao esgotamento dos recursos naturais e à cada vez maior concentração de gases de efeito estufa na atmosfera, é fundamental desacoplar o desenvolvimento do uso de novos recursos naturais e simultaneamente gerar menos emissões de $\mathrm{CO}_{2}$.

Dentro deste contexto, é de fundamental importância o desenvolvimento de tecnologias e soluções inovadoras que permitam obter ganhos do ponto de vista de sustentabilidade, seja pelo aproveitamento de resíduos para uma construção mais eficiente, segura, de qualidade e com redução do impacto ambiental, seja pelo desenvolvimento de novos materiais e processos. A pesquisa científica, com a posterior transferência para o mercado é um caminho sem volta.

Esta edição, v26, n.4, traz 51 artigos com forte cunho de inovação e sustentabilidade, abordando temas como o desenvolvimento de novos materiais inovadores ou da utilização de resíduos; ou ainda a busca de maior qualidade, segurança, durabilidade e menor custo, através de materiais mais adequados ao uso, o emprego de materiais alternativos a outros de grande impacto ambiental, do desenvolvimento de novos processos, do domínio do comportamento dos materiais, de equipamentos ou métodos de avaliação; ou ainda através de proposta de captura de $\mathrm{CO}_{2}$.

\section{BIBLIOGRAFIA}

[1] UN HABITAT. UN-Habitat Global Country Activities Report: 2015. Kenya: United Nations, 2015. Disponível em: <https://unhabitat.org/books/un-habitat-global-country-activities-report-2015-increasingsynergy-for-greater-national-ownership/>. Acesso em: 01 out. 2021.

[2] UN Enviromental. Decoupling natural resource use and enviromental impacts from economics growth, 2011. Disponível em: < https://wedocs.unep.org/handle/20.500.11822/9816>.Acesso em: 01 out. 2021.

ORCID

Angela Borges Masuero | https://orcid.org/0000-0001-9117-8346 